DOI: https://doi.org/10.32836/2521-666X/2019-65-13

УДК 338.27

\author{
Петрук І.П. \\ аспірант кафедри менеджменту публічного \\ управління та персоналу, \\ Тернопільський національний економічний \\ університет
}

\title{
Petruk Inna
}

Ternopil National Economic University

\section{ТЕОРЕТИКО-МЕТОДИЧНІ АСПЕКТИ ОЦНКИ АНТИКРИЗОВОГО УПРАВЛІННЯ НАЦІОНАЛЬНОЇ ЕКОНОМІКИ}

\section{THE TEORETICAL-METHODICAL ASPECTS OF ANTICRISIS MANAGEMENT ASSESSMENT OF NATIONAL ECONOMY}

У статті сформульовано методичний підхід до оиінки антикризового управління національної економіки, що дасть змогу ідентифікувати реальний стан економіки, визначити потенціал та стратегічну позицію національної економіки на основі економіко-математичного моделювання. Обгрунтовано відповідно до сучасних реалій найбільш придатні показники, підхід та етапи оцінки результативності антикризового управління украӥнською економікою. Запропонований методичний підхід до оцінки результативності антикризового управління національної економіки має прикладне практичне значення, враховує багато факторів, розглядає великий масив вхідних даних через використання сучасних комп 'ютерних технологій, що дасть змогу отримати інформацію у компактному вигляді та оптимально вибрати стратегію розвитку українскої економіки на тривалу перспективу.

Ключові слова: антикризове управління, національна економіка, кризові явища, методи, показники, методичне забезпечення, ризикове середовище.

В статье сформулирован методический подход к оценке антикризисного управления национальной экономики, что позволит идентифицировать реальное состояние экономики, определить потенциал и стратегическую позицию национальной экономики на основе экономико-математического моделирования. Обоснованы согласно современным реалиям наиболее пригодные показатели, подход и этапы 
оценки результативности антикризисного управления украинской экономикой. Предложенный методический подход к оценке результативности антикризисного управления национальной экономики имеет прикладное практическое значение, учитывает много факторов, рассматривает обиирный массив входных данных через использование современных компьютерных технологий, что позволит получить информацию в компактном виде и оптимально выбрать стратегию развития украинской экономики на длительную перспективу.

Ключевые слова: антикризисное управление, национальная экономика, кризисные явления, методы, показатели, методическое обеспечение, рисковая среда.

In a risk environment, it is necessary to create a comprehensive system of methodological support that will allow not only to implement the methodology of evaluating the effectiveness of crisis management of the national economy, but also to forecast the situation for the near strategic perspective. In scientific circles there is no single approach to the definition of methods of evaluation of crisis management and the use of methodological tools. Therefore, the need to develop an effective methodology for evaluating the effectiveness of crisis management of the national economy, the study of its criteria and methods of assessment determine the relevance of this article. The article substantiates the algorithm for evaluating the performance of national economy management, which provides identification of the real state of the economy, potential and strategic orientation in the future. The method of estimation of results of crisis management of national economy which is carried out in three stages is offered, namely: formation of theoretical and methodological bases and development of system of indicators of assessment of national economy, determination of methodology of multidimensional statistical evaluation of effectiveness of crisis management, choice of the final variant of further development of national economy in competitive environment. The developed methodological approach to the assessment of the crisis management of the national economy involves the study of all major factors of influence and presents a system of indicators that allow to assess the peculiarities of the development of the national economy in the context of globalization. The most appropriate indicators for assessing the effectiveness of crisis management of the Ukrainian economy are substantiated in accordance with current realities, and two groups of indicators are identified in the research process, namely: "target indicators", that is, those that reflect the phenomenon or process targeted by anticrisis measures and "indicators-results" - illustrate changes resulting from management actions. The assessment of crisis management according to a certain methodology is performed on the basis of correlation-regression analysis, which will allow to determine the degree of impact, potential and reserves of crisis management of the national economy and the method of artificial neural networks, which will allow to develop perspective directions of development and to forecast possible situations of development in risky environment. Research of crisis management of economy by a certain method will allow to receive high-quality information on management of the national economy, will determine its strategic orientation in the future, will allow to avoid possible risks and to identify alternative ways of its optimization.

Key words: crisis management, national economy, crisis phenomena, methods, indicators, methodological support, risk environment.

Постановка проблеми. Нові економічні умови становлення ринкового механізму, нестабільність політичного середовища та вибір стратегічних напрямів розвитку національної економіки формують необхідність створення цілісної системи методичного забезпечення розвитку, що дасть змогу не тільки реалізувати методику оцінки антикризового управління національної економіки, а й спрогнозувати ситуацію на найближчу стратегічну перспективу, яка буде спрямована на своєчасну локалізацію кризових явищ. Наукові дослідження до визначення методики оцінки антикризового управління та меха- нізму їх нейтралізації не визначили єдиного підходу у наукових колах. Тому необхідність розроблення ефективної методики оцінки антикризового управління національною економікою, дослідження іiі критеріїв та методів оцінки зумовлюють актуальність цієї статті.

Аналіз останніх досліджень і публікацій. Вагомий внесок у теорію дослідження методики антикризового управління національної економіки та вибору найбільш ефективних методів його здійснення зробили такі відомі вітчизняні науковці і фахівці, як С.М. Іванюта, В.О. Василенко, І.С. Малий, Л.О. Лігоненко, О.С. Кузьмін [7], 
3.С. Шершньова [9], а також зарубіжні вчені Е.М. Коротков, С.С. Мінаєв [2], А.В. Крутик, A.I. Муравйов та інші. Водночас потребує подальшого дослідження систематизація методичних основ та інструментів антикризового управління з подальшим удосконаленням напрямків їхнього розвитку.

Мета статті полягає у розробленні методичного підходу до оцінки антикризового управління національної економіки 3 використанням економіко-математичного моделювання відповідно до сучасних тенденцій розвитку глобальної економіки.

Виклад основного матеріалу дослідження. Сьогоднішні українські економічні реалії, від необгрунтованих управлінських рішень до нестабільної політичної ситуації, поставили перед економічною наукою завдання антикризового управління національної економіки у невизначеному середовищі. Це пов'язано 3 необхідністю оперативного реагування на нестабільну ситуацію, мінімізації наслідків впливу кризи на розвиток національної економіки та коригування структурної політики. У більшості досліджень проведено теоретичний аналіз національної економіки, але залишаються невисвітленими на національному рівні питання методики оцінки результативності антикризового управління національної економіки.

Методичне забезпечення оцінки результативності управління на підприємствах $€$ відносно повним, тоді як методики оцінки антикризового управління на макрорівні немає, системний підхід на теоретичному, законодавчому чи практичному рівні відсутній, попри надзвичайну актуальність проблеми антикризового регулювання національної економіки України. Тобто для забезпечення ефективності й неупередженості результатів антикризового управління необхідно правильно й обгрунтовано включати у його методику вищеназвані елементи. Виходячи 3 цього, нами запропоновано методику оцінки результатів антикризового управління, наведену на рисунку 1.

Визначення показників для оцінки результативності управління та наповнення етапів запропонованої методики (рис. 1) проводимо, дотримуючись запропонованого алгоритму дій:

- виокремлення структурних складників національної економіки;

- визначення номенклатури показників-індикаторів, що характеризують сферу національної економіки, на яку націлені антикризові заходи, а також тих, які відображають результат реалізованих дій;

- обгрунтування вибору індикаторів;

- моніторинг динаміки індикаторів;

- встановлення щільності взаємозв'язків між заданими параметрами для вилучення заходів, які не чинять значного впливу на стан національної економіки або, навпаки, відіграють найсуттєвішу роль;

- інтерпретація результатів та прогнозування розвитку процесу на основі нейромережевого моделювання;

- систематизація рекомендацій для поліпшення системи управління економікою в умовах кризи та формування досвіду з метою виходу із криз у майбутньому.

Системний підхід до оцінки результативності управління національною економікою за допомогою запропонованих етапів (рис. 1) забезпечує ідентифікацію реального стану економіки, потенціалу та стратегічної спрямованості у перспективі. Перевагою цісї методики є застосування показників глобального простору, які дозволять адекватно відобразити економічну ситуацію національної економіки у стратегічній площині.

В етапі 1 «Формування теоретико-методичних основ та розроблення системи показників оцінювання національної економіки» виділено систему показників для оцінки антикризового управління національної економіки та факторів глобального середовища, яка дозволить ідентифікацію можливих загроз та ризиків з метою їх своєчасного усунення, що дасть змогу суб'єкту розвиватись у стратегічній перспективі.

Проводячи вибір показників для запропонованої методики, потрібно орієнтуватися на такі, що найповніше будуть характеризувати можливості держави впливати на економічні 


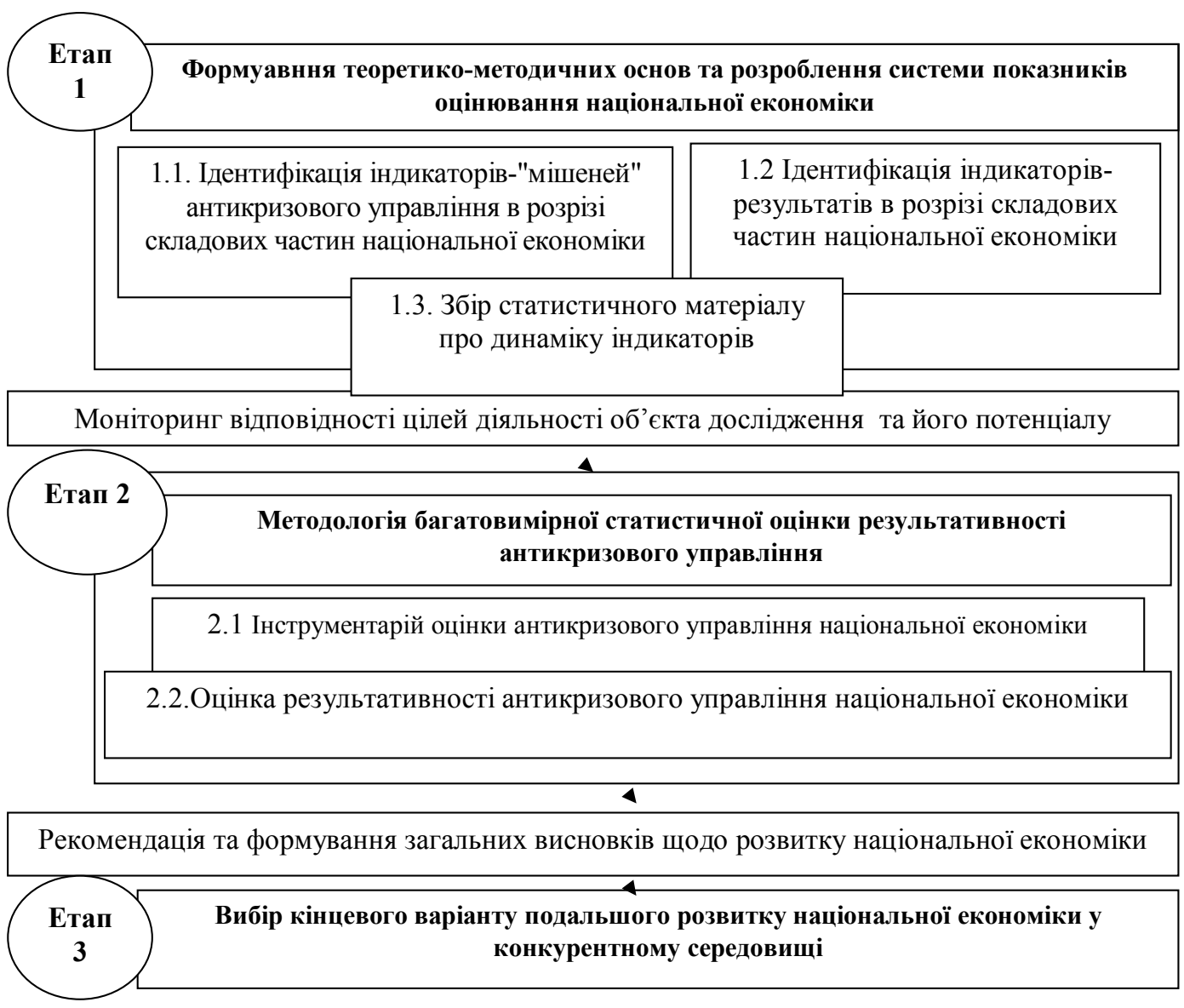

Рис. 1. Методика оцінки результатів антикризового управління національної економіки Джерело: розроблено автором самостійно

та соціальні процеси та детермінують зміни в інших, пов'язаних сферах. На рис. 1 наведений блок, який є чутливим до мінливості конкурентного середовища, а управлінські дії мають вживатися уповноваженими органами державної влади для врегулювання кризи у поєднанні з показниками, які відображають характер змін, що очікувано відбудуться в національній економіці зі введенням в дію антикризових інструментів. Першим індикатором, який проводить оцінку результативності антикризового управління, $є$ державні фінанси, які включають такі показники: скорочення дефіциту Державного бюджету України (на зниження частки державного боргу до ВВП; на динаміку відношення об- сягу сукупних платежів з обслуговування та погашення державного боргу до доходів державного бюджету); зниження рівня ухилення від оподаткування (на підвищення результатів діяльності суб'єктів господарської діяльності; планове виконання державного бюджету за податковими надходженнями); оптимізація перерозподілу ВВП через державний бюджет (на виконання державного бюджету за податковими надходженнями на запланованому рівні); зниження рівня облікової ставки НБУ (на зростання сукупних платежів з обслуговування та погашення державного боргу до доходів державного бюджету; на збільшення частки залучених депозитів до наданих кредитів населенню та бізнесу); нарощення 
золотовалютних резервів (на зниження відношення обсягу сукупних платежів з обслуговування та погашення ДБ до доходів державного бюджету; на спадну динаміку відношення державного боргу до ВВП; на зниження рівня інфляції); зниження рівня податкового навантаження (на збільшення позитивних результатів діяльності суб'єктів господарської діяльності (СГД), висхідна динаміка індексу Першої фінансової торговельної системи (ПФТС); виконання Державного бюджету України за податковими надходженнями).

Отже, оцінка результативності антикризового управління репрезентується ступенем впливу економіки, що включає: заходи, які стимулюють зростання рівня промислового виробництва, обсягу державних капітальних інвестицій, пожвавлення інноваційної діяльності підприємств, зумовлюють позитивне сальдо зовнішньоторговельного балансу - на зростання ВВП, приріст ВРП, підвищення котирувань індексу ПФТС; боротьбу з високим рівнем тіньової економіки (на покращення результатів діяльності; виконання бюджету за податковими надходженнями на запланованому рівні); стимулювання сукупного споживання, сукупного заощадження (на позитивну динаміку результатів діяльності СГД, заплановане виконання ДБУ за податковими надходженнями); перевищення частки залучених депозитів над часткою наданих кредитів (на позитивну динаміку результатів діяльності СГД; зростання рівня виконання бюджету за податковими надходженнями).

Результативність антикризового управління національної економіки характеризується соціальним забезпеченням, а саме: підвищення розміру мінімальної заробітної плати, прожиткового мінімуму (на зростання середнього рівня доходів населення; зниження частки населення з доходами нижче середнього; від'ємний приріст трудової міграціi); забезпечення спадної динаміки рівня безробіття (на збільшення середнього рівня доходів населення; зменшення питомої ваги населення 3 доходами нижче середнього; скорочення випадків трудової міграції; зниження навантаження непрацездатного населення на працююче; ско- рочення дефіциту Пенсійного фонду); підвищення середнього розміру пенсії (на зростання дефіциту Пенсійного фонду).

Наступним блоком показників, що характеризує антикризове управління національною економікою, виступає паливно-енергетичний комплекс, який визначає вплив на споживання енергоресурсів 3 метою його скорочення, спадна динаміка обсягу субсидій - на індекс імпортозалежності від енергоресурсів; на динаміку середнього рівня доходів населення.

В умовах нестабільного ринкового середовища включаємо показники сектору безпеки і оборони, тобто регулювання видатків Зведеного бюджету, що чинять суттєвий вплив на динаміку рівня фінансування Збройних Сил України.

Суттєвий вплив на управління національною економікою чинять усі функціональні блоки глобальної економіки, що роблять ii вразливою до екзогенних шоків, окремі 3 яких мають випадковий, інші - цілеспрямований характер. Нами запропоновано виділити таку групу показників для аналізу факторів глобального простору: притік прямих іноземних інвестицій до ВВП України; частка іноземного капіталу в статутному капіталі українських банків; міжнародні резерви НБУ; коефіцієнт покриття експортом імпорту; обсяг державного зовнішнього боргу.

Блок 1.1. «Ідентифікація індикаторів-»мішеней» антикризового управління в розрізі складових частин національної економіки» повинен дати оцінку економічного потенціалу досліджуваного суб'єкта та визначити ii зв'язок із антикризовими заходами з метою формування плану дій у перспективі. Індикатори-»мішені» антикризових заходів розглянуті у прямому зв'язку із суб'єктами управління, їх волевиявленням, інтересами, політичною волею, геополітичною ситуацією, глобальними перетвореннями. Основна інформація, яка отримана в процесі розрахунку цих індикаторів, свідчить про певний рівень активності управлінських дій у контексті забезпечення виходу з кризи.

Блок 1.2. «Ідентифікація індикаторів'результатів у розрізі складників національної 
економіки» в процесі оцінки дасть змогу показати зміни, що відбуваються внаслідок управлінських дій, тобто надасть повну внутрішню характеристику національної економіки. Результативні індикатори належать до внутрішньої характеристики національної економіки, іiі змін залежно від впливу суб'єктів-учасників управлінських відносин, а також у взаємозв'язку із макроекономічними та глобальними умовами. Наведений на рисунку блок 1.3. «Збір статистичного матеріалу про динаміку індикаторів» визначає динаміку досліджуваних показників та поєднує інформаційні дані глобальної і національної економіки, які потребують опрацювання великого масиву даних. Застосування системного підходу дасть змогу виокремити найвагоміші і не брати до уваги неінформативні показники, цим самим він максимально оптимізує комплекс показників.

На 2 етапі «Методологія багатовимірної статистичної оцінки результативності антикризового управління» інтегральний підхід дасть змогу визначити стійкість національної економіки та її прихований потенціал, який включає усю сукупність концепцій та методів, адаптованих до умов зовнішнього i внутрішнього середовища. Побудова системи оцінки результативності антикризового управління національною економікою в умовах глобалізації, вважаємо, повинна грунтуватися на визначенні тих інтересів у сфері розбудови економічної системи, які є необхідними для формування належного фінансового потенціалу держави та позитивного іміджу країни на світовій арені. Результати аналізу дозволять розробити стратегію відповідно до потенціалу національної економіки та іiї рівня розвитку.

Суть блоку 2.1 «Інструментарій оцінки антикризового управління національної економіки» полягає у здійсненні аналізу досліджуваних показників антикризового управління, на основі якого буде здійснюватися прогнозування антикризового управління національної економіки в умовах глобалізації. В основу цього аналізу покладено математичне моделювання, що дозволить встанови- ти взаємозв'язок між «мішенями» антикризового управління та його результатами, що дозволить визначити між ними рівень тісноти зв'язку. Застосування математичного апарату дасть змогу виявити суттєвість впливу внутрішнього середовища на національну економіку та можливі резерви для визначення тенденцій подальшого розвитку.

Блок 2.2 «Оцінка результативності антикризового управління національної економіки». Проводиться оцінка національної системи антикризового управління, яка сформована системою показників, що дозволить врахувати потенціал досліджуваного об'єкта та зміни зовнішнього середовища. Враховуючи сучасні методики аналізу результатів діяльності підприємств і практику, можна стверджувати, що система методичних прийомів аналітичної оцінки фінансових індикаторів загалом консервативна. Водночас необхідно брати до уваги новітні тенденції розвитку стратегічного управління, що визначать напрям подальшого розвитку національної економіки.

На 3 етапі «Вибір кінцевого варіанту подальшого розвитку національної економіки у конкурентному середовищі», грунтуючись на результатах дослідження антикризового управління національної економіки, слід визначити стратегічну спрямованість національної економіки та розробити пропозиції щодо усунення недоліків у стратегічній перспективі розвитку. 3 позиції оптимальності та раціоналізації прийняття управлінських рішень адекватно повинна вдосконалюватись і система державного управління 3 урахуванням найбільш пріоритетних напрямів розвитку.

Існування такої значної кількості методів пов'язане 3 двома причинами: наявністю різних видів антикризового управління підприємством та різною природою і причиною самих кризових явищ. Статистичний метод застосовується нами на початковому етапі аналізу антикризового управління 3 метою збору та обробки інформації, надаючи перевагу тій інформації, яка найповніше відображає реальний стан національної економіки в умовах глобалізації. 




\section{Рис. 2. Методи оцінки результативності антикризових заходів}

Джерело: складено автором самостійно

Використання тактичних методів у антикризовому управлінні сприяє якісному покращенню характеристики діяльності підприємств та дозволить швидко вийти зі стану кризи. Проте здебільшого цих методів не досить для усунення основної причини кризового стану - неефективної системи управління. 3 метою адекватної оцінки результативності антикризового управління необхідно використовувати методи, що включа- ють великий спектр показників та швидко їх опрацьовують.

Стратегічні методи антикризового управління економікою спрямовані на визначення стратегічних позицій показників результативності антикризового управління 3 метою запобігання кризових процесів в економіці. Для цього на рівні держави розробляються антикризові заходи, які передбачають періодичне дослідження стійкості національної 
економіки, визначення можливих масштабів кризи, вивчення основних чинників кризи, запровадження внутрішніх механізмів стабілізації економіки та визначення напрямів розвитку у перспективі. Застосування стратегічних методів не дозволяє усунути причини кризи, тому для повнішого дослідження необхідно застосовувати економіко-математичні методи.

Застосування економіко-математичних методів дає змогу оцінити показники результативності національної економіки, визначити вплив факторів та прогнозувати тенденції їхнього розвитку. Оскільки теоретичний аналіз не дозволяє відстежувати зв'язок між факторами впливу і результуючим показником оцінки антикризового управління національної економіки, доцільно буде застосувати кореляційно-регресійний аналіз. Теорія кореляційно-регресійного аналізу передбачає встановлення зазначених зв'язків між досліджуваними показниками та дозволить адекватно розробляти управлінські рішення 3 метою встановлення стійкої національної економіки.
Сьогодні посилений інтерес до економікоматематичних методів, що стають важливим інструментом отримання глибоких і повних знань про кількісні і якісні сторони управління національної економіки та виступають основою для розроблення рекомендацій щодо подальшого розвитку антикризового регулювання.

Висновки і пропозиції. Проаналізувавши вищезазначене, ми дійшли висновку, що використання запропонованої методики оцінки результативності антикризового управління національної економіки дасть можливість отримати високоякісну інформацію про управління національною економікою, визначить iï стратегічну спрямованість у перспективі, дасть змогу уникнути можливих ризиків та визначить альтернативні шляхи іiі оптимізації. Вдосконалення методичного підходу до оцінки антикризового управління та запропонованих рекомендацій становить перспективу подальших наукових досліджень 3 метою формування стратегії розвитку національної економіки, враховуючи всі фактори впливу.

\section{Список літератури:}

1. Антикризове управління національною економікою: монографія / І. Малий, І. Радіонова, Л. Ємельяненко та ін. ; за заг. ред. І. Малого. Київ: КНЕУ, 2017. 368 с.

2. Антикризисное управление: учеб. пособие для вузов / Московский гос. авиац. ин-т (техн. ун-т) ; под ред.: Э.С. Минаева, В.П. Панагушина. Москва: ПРИОР, 1998. 432 с.

3. Василенко В.О. Антикризове управління підприємством. Вид. 2-ге, випр. і допов. Київ: Центр навч. л-ри, 2005. 504 с.

4. Іванюта С.М. Антикризове управління: навч. посібник. Київ: Центр учбової літератури, 2007. $288 \mathrm{c}$.

5. Крутик А.В., Муравьев А.И. Антикризисный менеджмент. Санкт-Петербург: Питер, 2001. $432 \mathrm{c}$.

6. Коротков С.М. Антикризисное управление. Москва: ИНФРА-М, 2005. 620 с.

7. Кузьмін О.С. Інноваційні підходи в системі економіко-математичного моделювання фінансово-кредитної діяльності виробничо-господарських структур. Проблеми фінансово-кредитного регулювання інноваційного розвитку виробничо-господарських структур / за заг. ред. О.С. Кузьміна, І.В. Алєксєєва. Львів: Вид-во Національного університету «Львівська політехніка», 2007. Розділ 7. С. 125-149.

8. Лігоненко Л.О. Антикризове управління підприємством: теоретико-методологічні засади та практичний інструментарій: монографія. Київ: Київ. нац. торг.-екон. ун-т., 2001. 580 с.

9. Шершньова 3.С., Багацький В.М., Гетманцева Н.Д. Антикризове управління підприємством: навч. посіб. ; за заг. ред. 3.С. Шершньової. Київ: КНЕУ, 2007. 680 с.

\section{References:}

1. Malyi I., Radionova I., Yemelianenko L. et al. (2017), Antykryzove upravlinnia natsionalnoiu ekonomikoiu [Anti-crisis management of the national economy]. Kyiv: KNEU. (in Ukrainian). 
2. Minaev Ye.S., Panagushin V.P. (eds.) (1998), Antikrizisnoye upravleniye [Anti-crisis management]. Moscow: PRIOR. (in Russian).

3. Vasylenko V.O. (2005), Antykryzove upravlinnia pidpryiemstvom [Anti-crisis management of the enterprise]. Kyiv: Tsentr navch. 1-ry. (in Ukrainian).

4. Ivaniuta S.M. (2007), Antykryzove upravlinnia [Anti-crisis management]. Kyiv: Tsentr uchbovoi literatury. (in Ukrainian).

5. Krutik A.V., Muravyev A.I. (2001), Antikrizisnyy menedzhment [Anti-crisis management]. St. Petersburg: Piter. (in Russian).

6. Korotkov Ye.M. (2005). Antikrizisnoye upravleniye [Anti-crisis management]. Moscow: INFRA-M. (in Russian).

7. Kuzmin O.Ye. (2007). Innovatsiini pidkhody v systemi ekonomiko-matematychnoho modeliuvannia finansovo-kredytnoi diialnosti vyrobnycho-hospodarskykh struktur [Innovative approaches in the system of economic and mathematical modeling of financial and credit activity of production and economic structures]. Problemy finansovo-kredytnoho rehuliuvannia innovatsiinoho rozvytku vyrobnycho-hospodarskykh struktur [Problems of financial and credit regulation of innovative development of production and economic structures]. Lviv: Vyd-vo Natsionalnoho universytetu "Lvivska politekhnika", chapter 7, pp. 125-149. (in Ukrainian).

8. Lihonenko L.O. (2001). Antykryzove upravlinnia pidpryiemstvom: teoretyko-metodolohichni zasady ta praktychnyi instrumentarii [Anti-crisis management of the enterprise: theoretical and methodological foundations and practical tools]. Kyiv: Kyiv. nats. torh.-ekon. un-t. (in Ukrainian).

9. Shershnova Z.Ye., Bahatskyi V.M., Hetmantseva N.D. (2007). Antykryzove upravlinnia pidpryiemstvom [Anti-crisis management of the enterprise]. Kyiv: KNEU. (in Ukrainian). 